\title{
Biodegradation of Cocoa Pod Husk Waste used Rot Fungi Consortium at Various Storage Times
}

\author{
Iradhatullah Rahim ${ }^{1}$, Jumardin ${ }^{2}$, Suherman ${ }^{3}$, Andi Nasruddin ${ }^{4}$ \\ \{iradhat76@gmail.com ${ }^{1}$,jumardin.pinrang@yahoo.com², emanagoge@gmail.com³ \\ andinasruddin@yahoo.com ${ }^{4}$ \} \\ 1,2,3 Department of Agritechnology, Faculty of Agriculture, Animal Husbandry, and Fisheries, \\ Universitas Muhammadiyah Parepare. Indonesia. 91113 \\ ${ }^{4}$ Department of Plant Pests and Diseases, Faculty of Agriculture, Universitas Hasanuddin. Indonesia. \\ 90245
}

\begin{abstract}
Cocoa pods is only considered as waste and was not utilized. Even though the utilization of cocoa pod husk waste was enough extensive, as a nutrient-rich fertilizer for plants. Degradation of cocoa pod husk waste naturally takes a long time, so could needed acceleration to degraded by using rot fungi. The purpose of this study was to determine the ability of rot fungi consortium to degraded cocoa pod husk waste at various time of storage. Then to know percentage of lignocellulotics, weight loss, $\mathrm{C} / \mathrm{N}$ ratio, and the nutrient content produced from the biodegradation process. The cocoa pod husk waste that has been chopped were inoculated with a consortium of Mycena sp., Tremella sp., and Pleurotus sp.. and fermented for 40 days at room temperature. The results showed that the lowest percentage of weight loss was on fresh cocoa pod husk, and the highest weight loss up to $2.3 \%$ in cocoa pod husk which was stored 30 days. The highest levels of $\mathrm{C}$ and $\mathrm{P}$ on cocoa pod stored 90 days and fermented 60 days, respectively at $8.98 \%$ and $0.59 \%$. It's showed that the best cocoa pods for compost were 90 days stored. Consortium of Mycena sp., Tremella sp., and Pleurotus $\mathrm{sp}$. was a biodegradator for plantation crops waste that has the potential to be developed.
\end{abstract}

Keywords: Storage times, Consortium, Biodegradator, Fresh cocoa pod husk.

\section{Introduction}

Cocoa pod husk was one of the by-products of cocoa that has not been utilized optimally. The cocoa pod is generally immediately disposed of as waste, even though this cocoa pod waste can be processed into something more useful. Some studies on the use of cocoa pod include making flour [1][2], and making pectin extract [3]. In addition, cocoa pod is rich in nutrients and can be used as a growing medium for plants so that it can be used as compost.

Utilization of cocoa pods husk as compost will increase the availability of organic fertilizers which can reduce the level of dependence on chemical fertilizers. In addition, it can reduce environmental pollution due to cocoa pod husk which are only stacked and even dumped in rivers. The cocoa pod husk waste if not utilized will be a source of pathogenic media. However, the utilization of cocoa pod waste has limiting factors such as low nutritional quality due to high crude fiber content $(40.03 \%)$, the presence of theobromine alkaloids $(0.17 \%-0.22 \%)$, and protein $(22 \%)$ [4]. According to [5], crude fiber in cocoa pods 
consisted of cellulose $36.23 \%$, hemicellulose $1.14 \%$, and lignin $20 \%-27.95 \%$. The lignin content in cocoa pods is greater than cellulose, which it is around $38.78 \%$ [4].

Several processing techniques can done to reduce the crude fiber content in cocoa pod [6]. One of the biological processing techniques by utilizing organisms which are capable to producing cell wall degrading enzymes such as cellulase, hemicellulase, and lignin breaking enzymes. Some groups of organisms are reported to be able to degrade lignin, cellulose, and hemicellulose compounds were fungi. Fungi are lignocellulolytic organisms that have ability in decomposing lignin, cellulose, and hemicellulose. There are three groups of fungi that can decompose wood components (lignocellulose), namely brown rot fungi, white rot fungi, and soft rot fungi [7].

Based on the considerate that rot fungi is the most active decomposer, this study was conducted on cocoa pods at various lengths of storage. The aimed was to see the degeneration ability of the rot fungi consortium, as well as to find out the best storage time cocoa pods husk for compost.

\section{Materials and Methods}

\subsection{Isolation of Rot Fungi from Cocoa Plantation}

Isolates of rot fungi were obtained from decayed cocoa stems in cocoa plantations in Bila Village of Pitu Riase $\left(3^{\circ} 38^{\prime} 19.5^{\prime \prime} S+120^{\circ} 05^{\prime} 08.5^{\prime \prime E}\right)$, Sidrap District, South Sulawesi, Indonesia. Fruiting bodies of 10 species of rot fungi were collected and brought back to laboratory for isolation. The fruit bodies were cut into small pieces $(1 \times 1 \mathrm{~cm})$ and then surface sterilized with $70 \%$ alcohol, rinsed twice with sterile water, and placed onto separate sterile filter paper. A piece of each colony $(Q 7 \mathrm{~mm})$ was transferred into a Petri dish $(Q 9 \mathrm{~cm})$ containing potato dextrose agar (PDA) medium after the fungal isolates grew and then incubated in room temperature for 7 days. The isolates were then coded according to the name of place of origin, after sub-cultured and purified [8].

\subsection{Composting Cocoa Pod Husk Waste in the Different Storage Time by Isolates Consortium Rot Fungi}

Isolates on reproduction media incubated at room temperature for 7 days. Cocoa pod husk waste in the different storage time were fresh cocoa pod husk, stored for 30, 60, and 90 days, chopped then mixed with sawdust, and chaff. Compost medium were moisten with water until $30 \%$ water content, then sterilized on temperature of $250{ }^{\circ} \mathrm{C}$ for 2 hours. Cocoa pod husk media then inoculated with consortium rot fungi isolates and fermented for 30 dan 60 days.

\subsection{Lignocellulotic Content Cocoa Pod}

Cocoa pods that had been stored for 20 days were cut into small pieces $(1-2 \mathrm{~cm})$ and then mixed with rice husks. The mixture was added with water until the percentage of $30 \%$ was achieved and then the mixture $\mathrm{pH}$ was adjusted to be within the range of $5.5-6$. The mixture was placed into bottles $(10 \mathrm{ml})$ and then sterilized at $250^{\circ} \mathrm{C}$ for 60 minutes using an autoclave. After the mixture cooled down, it was inoculated with rot fungi grown on PDA, either using a single species or in species consortia. The mixture was incubated in room temperature for 40 days, it was analyzed to determine the concentrations of lignin, cellulose, and hemicellulose by measuring the quantity of Acid Detergent Fibre (ADF) and Neutral Detergent Fibre [9]. 
Medium for cocoa pod husk waste at various lengths of storage, namely fresh cocoa pod husk, has been stored for 30 days, 60 days, and 90 days sterilized at $250^{\circ} \mathrm{C}$ for 60 minutes using autoclaves. The media was inoculated with a consortium of three rot fungi isolates as bio activators and incubated for 60 and 90 days at room temperature. The media was analysed the organic $\mathrm{C}$ content with the Walkey and Black methods [10]. Compost weights was measured before and after the fermentation to see the percentage of weight loss using the formula [11]:

$\underline{\mathrm{Wt}}-\mathrm{W} 0 \times 100 \%, \mathrm{Wt}=$ final weight, $\mathrm{W} 0=$ previous weight

$\mathrm{Wt}$

\subsection{Data Analysis}

The experiment following Randomized Completed Block Design with 4 treatments and 3 replications (block). All data was analysed through computer base statistical program Microsoft Excel. Significant effect of treatments were determined by analysis of variance and treatment means were compared at 5\% level of significance by Honestly Significance Difference (HSD).

\section{Result and Discussion}

\subsection{The Selected Rot Fungi from Cocoa Plantation}

There were three fungi were chosen which have the highest ability to degrade and produce nutrients. The rot fungi were Mycena sp, Tremella sp, and Pleurotus sp (Figure 1). Tremella $s p$ and Pleurotus $s p$ have the highest ability to degrade lignocellulose and produce nutrients [12], while Mycena sp has the highest ability to produced Indole Acetat Acid (data not shown). The selected rot fungi were used as rot fungal consortium in the biodegradation tests. 


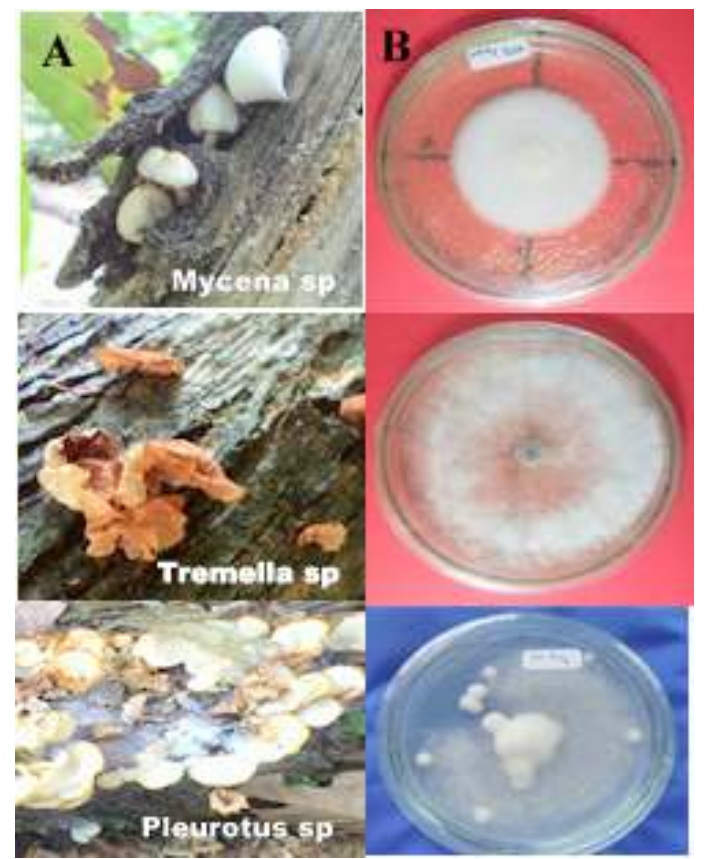

Figure 1. Three selected rot fungi from decayed cocoa plant. In the cocoa stem (A) and isolates in PDA medium 7 days after incubation (B).

\subsection{Biodegradation of Cocoa Pod Husk on Various Storage Times}

The consortium of three superior rot fungi isolates inoculated on cocoa pods for various storage time, namely fresh cocoa pod husk, cocoa pod husk waste that have been stored for 30 days, 60 days, and 90 days (Figure 2). Cocoa pod husk colour is one of the maturity level indicators. Young cocoa pod is green, whitish green, or red according to the variety. The cocoa pod husk will escape when cooked from the inner skin and will turn yellow or orange [13]. Fresh cocoa pod husk is still bright or orange in color. The color of the cocoa pod husk will get darker after being released from the fruit (Figure 2).

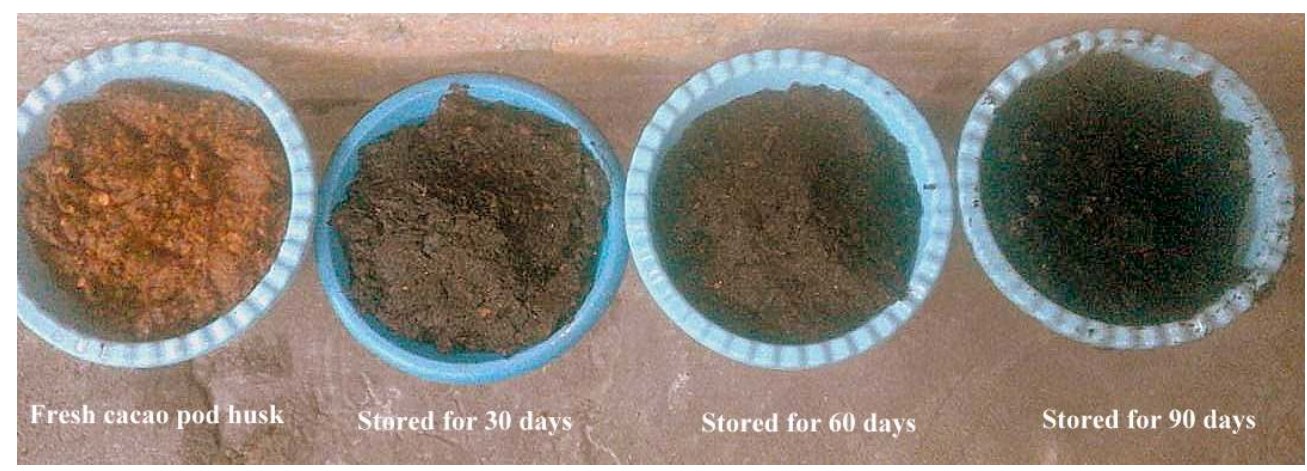

Figure 2. The chopped cocoa pod husk waste in the various of storage times. The longer it was stored, the darker the color was. 
The cocoa pods were fermented for 60 days using a consortium of rot fungi isolates. Compost of cocoa pod husk has decreased weight after fermentation. The percentage decrease of cocoa pod husk compost weight presented in Figure 3. It shows the percentage of decrease cocoa pod husk is lowest in the fresh cocoa pod husk and significantly different from other storage time treatments after it fermented for 60 days. The highest decrease weight to $2.3 \%$ in the in cocoa pod husk waste stored for 30 days was significant different than the decrease of fresh cocoa pod husk which it is only $0.099 \%$. The decrease of the weight of cocoa pods that have been stored for 60 days was only $0.82 \%$. Even if stored for 90 days, the weight loss is only $0.38 \%$ after fermentation for 60 days. It clearly showed that the longer of cocoa pods husk were stored, the rate of weight loss of cocoa pod husk is lower.

Decrease in weight occurs due to the activity of fungi which decompose organic matter. Although the weight decreases, the volume of organic matter tends to increase. [14] stated that mesophilic microorganisms that live at low temperatures $\left(10-45^{\circ} \mathrm{C}\right)$ its function to reduce particle size of organic matter so that the surface area of the material increases and accelerates the composting process. However, no reported basidiomycetes caused a decrease in weight in decayed wood exceeding 5.0\% [15]. The lowest value of weight loss on cocoa pod husk that have been stored for the longest, in this study, has been stored for 90 days or 3 months. It presumably because there has been a decrease weight naturally for a long time. So that when the fermentation done by rot fungi consortium, the rate of decrease cocoa pod husk weight tends to be very small. We suspect if cocoa pods are taken for 120 days, the probability of a decrease in weight is zero.

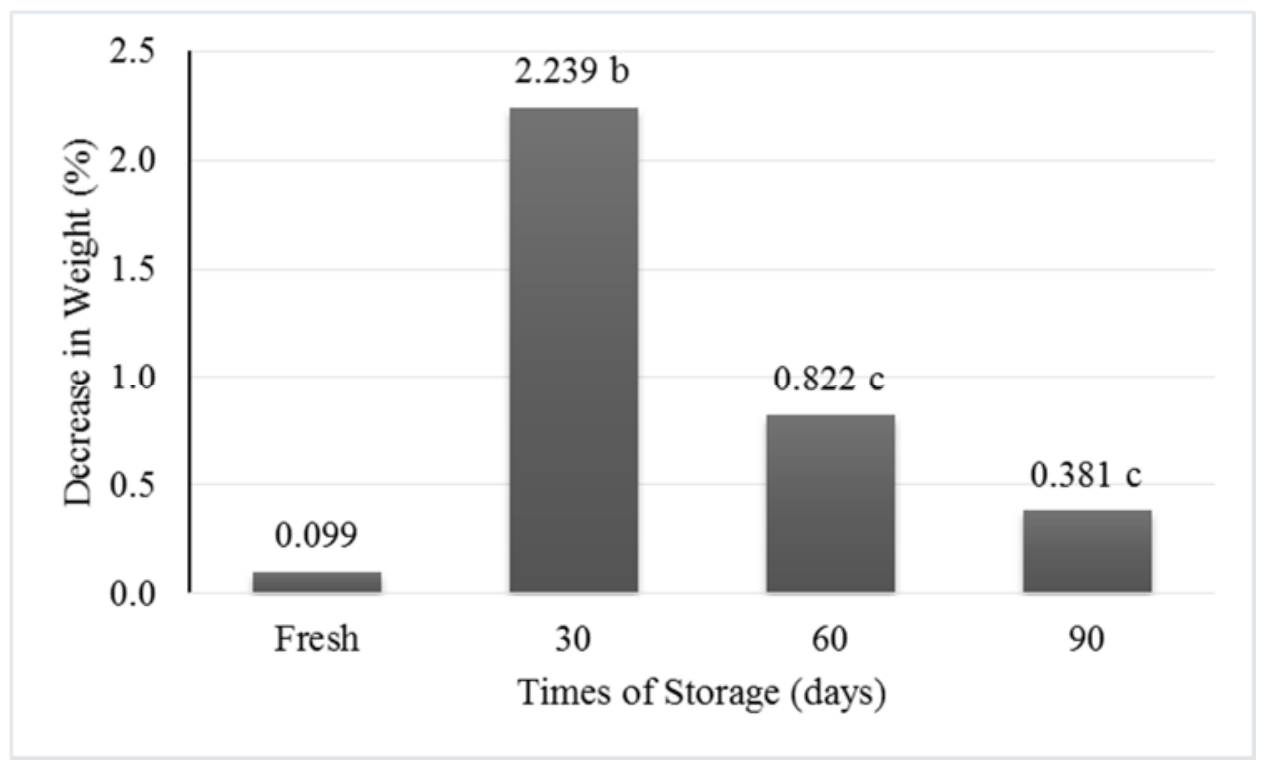

Figure 3. Percentage of decrease cocoa pod husk waste (\%) inoculated by consortium rot fungi in 60 days fermented.

The lignocellulotic content includes the content of hemicellulose, cellulose, and lignin before and after fermentation with the rot fungi consortium shown in Figure 4. Percentage of lignosellulotic levels in cellulose, hemicellulose, and lignin of cocoa pod husk waste fermented without rot fungi was higher than if it fermented by rot fungi. This shows that without rot fungi, the decomposition process more slowly. The fungi consortium 
consisting of Tremella sp, Pleurotus sp, and Mycena sp have the good degradation ability. Mycena $s p$ has the ability to break cellulose and lignin which it allows to be classified as white rot fungus. Mycena galopus is one of the species Mycena sp which it is the main decomposer of oak leaves, $80 \%$ of its mycelium was found in fallen leaves [16].

The ability of Pleurotus $s p$ to degrade lignin is due to its ability to produce degrading enzymes. [17] found 3 types of enzymes, namely manganese peroxidase (MnP), aryl-alcohol oxidase (AAO) and laccase, which were involved in lignin degradation. They were detected and measured during fermentation of wheat straw with 5 species of Pleurotus. The highest level is produced by $P$. pulmonarius. The study of enzymes secreted by Pleurotus ostreatus, namely laccase and aryl-alcohol oxidase together also results in a marked reduction in molecular mass of lignosulphonates [18].

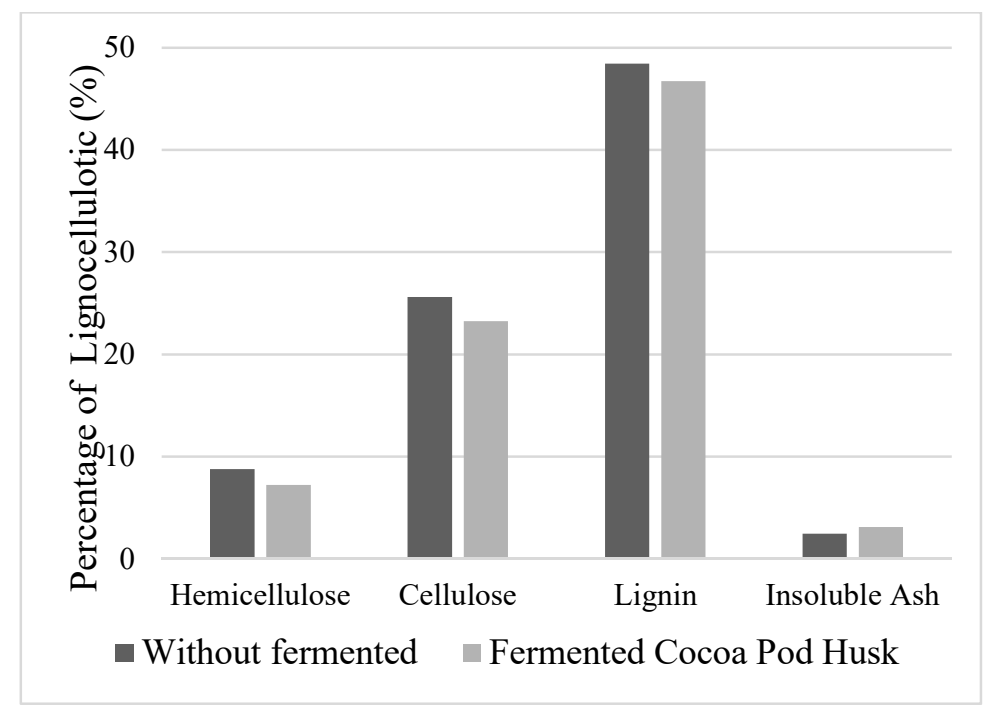

Figure 4. Lignocellulotic content of cocoa pod husk waste whitout fermentation and fermentation by rot fungi.

The level of compost maturity was characterized by a comparison between carbon content and nitorgen content or also called the $\mathrm{C} / \mathrm{N}$ ratio. In this study, if fermentation not done, the $\mathrm{C} / \mathrm{N}$ ratio on the cocoa pod husk at various storage times ranges from 21-27 (Table 1). The highest $\mathrm{C} / \mathrm{N}$ ratio found in the fresh cocoa pod husk. After biodegradation by the rot fungi consortium, the longer the cocoa pods were stored, the lower the $\mathrm{C} / \mathrm{N}$ ratio and even stability. The cocoa pod husk that has been stored for 90 days was either unfermented or fermented 30 and 60 days, the $\mathrm{C} / \mathrm{N}$ ratio was quite stable, which in 21-20. Cacao pod husk that has been fermented for 60 days, both fresh cocoa pod husk and those that have been stored 30,60 , and 90 days has the same $\mathrm{C} / \mathrm{N}$ ratio that is 20 . It shows the long fermentation for composting on cocoa pod husk is a maximum of 60 days. The $\mathrm{C} / \mathrm{N}$ ratio of cocoa pod husk compost in this study qualified of SNI 19-7030-2004 for compost, which requires a minimum of 10 and a maximum of 20 [19].

However, the optimum $\mathrm{C} / \mathrm{N}$ ratio has a range between $20-25$. It is ideal for maximum decomposition because there will be no release of mineral nitrogen from organic matter above the amount needed for microbial synthesis [20]. 
Tabel 1. $\mathrm{C} / \mathrm{N}$ ratio content of cacao pod husk in various storage times during fermentation

\begin{tabular}{lccc}
\hline Storage times of Cacao & \multicolumn{3}{c}{ C/N Ratio } \\
\cline { 2 - 4 } Pod Husk (days) & Without Fermentation & 30 days & 60 days \\
\hline Fresh & 27 & 21 & 20 \\
30 & 24 & 20 & 20 \\
60 & 25 & 25 & 20 \\
90 & 21 & 21 & 20 \\
\hline
\end{tabular}

\subsection{Nutrient Content of Fermented Cocoa Pod Husk by Rot Fungi Consortium}

Nutrient analysis showed that the nutrient content of cocoa pod husk was higher after fermentation compared to the fresh one. The longer fermentation the higher nutrient content. Even after 30 days, nutrient levels was tend to be constant (Figure 5). The lowest levels of $\mathrm{C}, \mathrm{N}, \mathrm{P}$, and $\mathrm{K}$ on the fresh cocoa pod husk, respectively $5.62 \%, 0.36 \%, 0.36 \%$, and $1.56 \%$. This shows that the fresh cocoa pod husk is not so good to be used as compost and should be stored long enough. Figure 5 also showed that the highest $\mathrm{C}$ and $\mathrm{P}$ levels were treated with cocoa pods husk which were stored 90 days and fermented 60 days, which were $8.98 \%$ and $0.59 \%$ respectively. This shows that the longer cocoa pod husk stored and the longer of the fermentation, $\mathrm{C}$ and $\mathrm{P}$ increasingly available to the plant. Although it is not yet known whether the increase is constant or will decrease after reaching the peak. [21] showed that $\mathrm{N}$ levels in Avicenna marina litter had increased after decomposition of 15-105 days, and subsequently decreased. Similarly, the levels of $\mathrm{P}$ and $\mathrm{C}$ nutrients in A. marina litter decreased after decomposition at 105-120 days.

The highest $\mathrm{N}$ and $\mathrm{K}$ levels in the cacao pod husk were stored 30 days and fermented 30 days, that is $0.45 \% \mathrm{~N}$ and $2.97 \% \mathrm{~K}$ (Figure 5). However, the results obtained by [22] were higher, that is $33.76 \% \mathrm{C}$-organic, and $2.41 \% \mathrm{~N}$ after cocoa pods were inoculated with Pleurotus pulmonarius and incubated for 30 days. Nitrogen is needed by microorganisms to synthesize protoplasm. If $\mathrm{N}$ less availability, it will reduce the ability of the fungi to decompose carbohydrates. As for plants, $\mathrm{N}$ is needed to form amino acids, enzymes, proteins, and nucleic acids [23][24]. The content of cocoa pod husk compost inoculated with rot fungi shows the nutrient content that microbes can release. Nutrient content of cocoa pods is quite high, [25] reports that $61 \%$ of the total nutrient of cocoa pods were stored on the cocoa pods husk. 


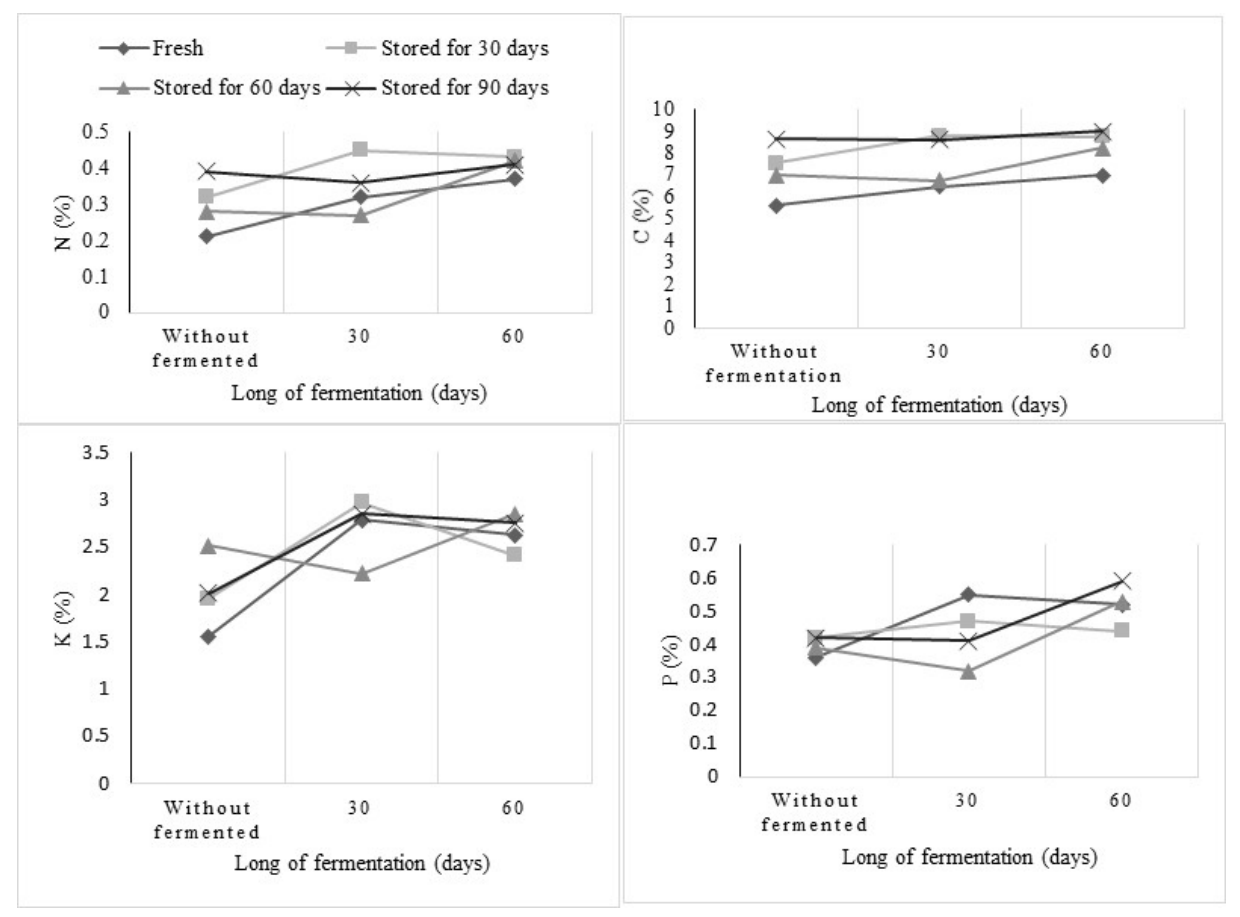

Figure 5. Nutrient content of fresh cocoa pods husk has been stored 30 days, 60 days, and 90 days in the 30 and 60 days long fermentation.

\section{Conclusion}

Biodegradation of cocoa pod husk waste with a rot fungi consortium, namely Mycena $s p$, Tremella $s p$, and Pleurotus $s p$ would increase the weight of organic matter, both on fresh cocoa pods or stored at 30,60 , or 90 days. In addition, it can reduce lignocellulotic levels and reduce the $\mathrm{C} / \mathrm{N}$ ratio of cocoa pods to the ideal limit of 20 at the 60 days long fermentation. The highest levels of $\mathrm{C}$ and $\mathrm{P}$ were treated with cocoa pods husk which had been stored for 90 days and fermented 60 days, which were $8.98 \%$ and $0.59 \%$, respectively. The highest levels of $\mathrm{N}$ and $\mathrm{K}$ in the cocoa pods husk which stored 30 days and fermentation of 30 days, that is $0.45 \% \mathrm{~N}$ and $2.97 \% \mathrm{~K}$. The fresh cocoa pod husk showed the highest $\mathrm{C} / \mathrm{N}$ ratio and the lowest nutrient content than it stored in 30, 60 and 90 days.

\section{Acknowledgement}

Thanks to DRPM Dikti which funded this study in Applied Research Fund.

\section{Refferences}

[1] Supriyanto, 1989. Karakterisasi Tepung Kulit Buah Kakao. Laporan Penelitian FTP UGM. Yogyakarta.

[2] Muttaqin, I., 1996. Tepung Kulit Buah Kakao sebagai Campuran Pembuatan Roti Tawar. Skripsi FTP UGM. Yogyakarta. 
[3] Endah, C.N., 1990. Optimasi Ekstraksi Pektin Kulit Buah Kakao. Skripsi FTP UGM. Yogyakarta.

[4] Laconi, E.B., 1998. Peningkatan Mutu pod Kakao Melalui Amoniasi dengan Urea dan Biofermentasi dengan Phanerochaete chriysosporium dan Penjabarannya ke dalam Ransum Ruminansia. Program Pasca Sarjana Institute Pertanian Bogor. Bogor.

[5] Amirroenas, D. E., 1990. Mutu Ransum Berbentuk Pellet Dengan Bahan Serat Biomassa POD Coklat Untuk Pertumbuhan Sapi Perah Jantan. Tesis Fakultas Pascasarjana, Institut Pertanian Bogor. Bogor.

[6] Preston, T.R. dan R.A. Leng, 1987. Matching Ruminant Production System with Available Resources in The Tropics and Subtropics. Penambul Books Armidale. Australia.

[7] Tillman, A.D., H. Hartadi, S. Reksohadiprodjo, S. Prawirokusumo, dan S. Lebdosoekojo. 1998. Ilmu Makanan Ternak Dasar. Gadjah Mada University Press. Yogyakarta.

[8] Choi, Y.W., Hyde, K.D. and Ho, W.H. Single spore isolation of fungi. Fungal Diversity 1999; 3:29-38.

[9] Van Soest, P.J., 1976. New Chemical Methods for Analysis of Forages for The Purpose of Predicting Nutritive Value. Pref IX International Grassland Cong.

[10] Schulte E., B. Hoskins., 2011. Recommended Soil Testing Procedures for the Northeasten United States. Cooperative Bulletin No.493, p 63-74.

[11] Gautam., S.P.,Bundela, P.S, Pandey, A.K, Jamaluddin, Awasthi, M.K, Sarsaiya, S., Diversity of Cellulolytic Microbes and the Biodegradation of Municipal Solid Waste by a Potential Strain. International Journal of Microbiology Vol.2012. Hindawi Publishing Corporation.

[12] Rahim, I., Nasruddin, A., Kuswinanti, T., Asrul, L., \& Rasyid, B. (2018). Utilization of Cocoa Pod Husk Waste Composting by Tremella Sp and Pleurotus Sp as A Medium to Growth of Cocoa Seedling. IOP Conference Series: Earth and Environmental Science, 156(1), 1-11. http://doi.org/10.1088/1755-1315/156/1/012012

[13] Sari, K. (2016). Pengaruh Indeks Kematangan Buah Kakao (Theobroma Cacao L.) Dan Massa Tumpukan Terhadap Kualitas Hasil Fermentasi Biji Kakao Di Wilayah Gedong Tataan, Kabupaten Pesawaran, Lampung. Universitas Lampung.

[14] Djuarnani, N., Kristian, dan Budi S. S. 2005. Cara Cepat Membuat Kompos. AgroMedia Pustaka. Jakarta.

[15] Fukusawa, Y.,Osono, T., Takeda, H., 2011. Wood decomposing abilities of diverse lignicolous fungi on nondecayed and decayed beech wood. Mycologia, 103(3):474482.

[16] Webster, J., \& Weber, R. (2007). Introduction to Fungi (Third). Camridge University Press.

[17] Camarero, S., Martínez, M. J., Martínez, A. T. 1997. Lignin-degrading enzymes produced by Pleurotus species during solid state fermentation of wheat straw in Advances in Solid State Fermentation:335-345.(eds) Roussos, S.,Lonsane, Raimbault, M. Gonzalez, V.G, Proceedings of the $2^{\text {nd }}$ International Symposium on Solid State Fermentation FMS·9S. Montpellier, France.

[18] Marzullo L., Cannio, R., Giardina, P, Santini, M.T., 1995. Veratryl alcohol oxicase from Pleurotus ostreatus participates in lignin biodegradation and prevents polymerisation of laccase-oxidized substrates. Journal of Biological Chemeestry, 270 p 3827-3828.

[19] National Standardization Agency, 2004. Specified of domestic compost and Organics. SNI 19-7030-2004.

[20] Rao, S., 2010. Mikroorganisme tanah dan pertumbuhan tanaman. Penerbit UI Press. Jakarta. 
[21]Yunasfi, 2006. Dekomposisi Serasah Daun Avicennia marina oleh Bakteri dan Fungi pada Berbagai Tingkat Salinitas. Disertasi tidak diterbitkan. Sekolah Pascasarjana Institut Pertanian Bogor, Bogor.

[22] Adenipekum, C. ., \& Dada, O. . (2013). Biodegradation of Three Agricultural Wastes by a White-rot Fungus Pleurotus pulmonarius (Fries) Quetlet C. O. Adenipekun. Nature and Science, 11(2), 19-25.

[23] Moore-Landecker, E. 1990. Fundamentals of The Fungi. Fourth Edition. Prentice Hall, Englewood. New Jersey.

[24] Fisher,R.F., and D.Binkley, 2000. Ecology and Management of Forest Soil. Third Edition. John Wiley and Sons, Inc. New York, Chichester, Weinheim, Brisbane, Singapore, Toronto.

[25] Isroi, 2007. Pengomposan Limbah Kakao. Makalah disampaikan pada Pelatihan TOT Budidaya Kopi dan Kakao. Pusat Penelitian Kopi dan Kakao, Jember. 